\title{
A joke on precision? Revisiting "precision" in the school mathematics discourse
}

\author{
Ulrika Ryan ${ }^{1}$ (D) $\cdot$ Anna Chronaki ${ }^{1,2}$ (I)
}

Published online: 30 July 2020

(C) The Author(s) 2020

\begin{abstract}
This paper discusses the place of precision in mathematics education by exploring its role in curricular guidelines and in classroom life. By means of a joke on precision delivered by a school student in South Sweden, our study focuses on student participation in mathematical tasks that require precision in processes of measuring and reasoning. The paper uses theories on humour and inferentialism to revisit the normative place of "precision" in mathematics classroom discourse.
\end{abstract}

Keywords Precision $\cdot$ Mathematical discourse $\cdot$ Joke-event $\cdot$ Humour $\cdot$ Inferentialism

\section{Introduction}

During a math class, four grade 5 students - two girls of Swedish and two boys of immigrant background-were working on a task of recognising and constructing angles of varied degrees, measuring them and reasoning about right, obtuse and acute types of angles. Their work soon turned into a playful competition around mathematical precision. On the spur of the moment, Greta, one of the girls, joked about angle precision, but her joke appeared to go unnoticed.

Episode 1: a joke on precision, Skåne, Sweden, April 24, 2017.

A first reaction to Greta's joke in the context of transcribing this episode was to consider it an offensive act directed from the competent "winning" girls' towards the "losing" boys' team. Greta exclaimed her joke as she and Eva were measuring a right angle sketched by the boys. The girls measured the boys' angle even though they had been instructed to make their

Ulrika Ryan

ulrika.ryan@mau.se

1 Malmö University, Malmö, Sweden

2 University of Thessaly, Volos, Greece 
judgment for angle category as acute, obtuse or right in approximation by observing and comparing. Greta jokingly exclaimed "It is not a right angle... It is an obtuse angle. It is 91 [degrees]". However, her exclamation did not evoke mirth. Greta then said, "I was just joking...That is if you measure it exactly ...." Since none of the students laughed, it is reasonable to ask whether Greta's exclamation qualifies as a joke just because Greta herself said that she was "just joking". Whether or not to consider Greta's utterance a joke raises dilemmas about how to perceive jokes or humour as an intrinsic component of classroom life relations.

Joking, laughing and finding situations humorous appear to be a human exercise, a way to cope with life's uncertainties, incongruences and complexities. What we find funny, and when we find things to be funny, is situated in cultural meanings (LaFollette \& Shanks, 1993). Humour is sensitive to both content itself and the dynamics of the event where the joke is performed (Hurley, Dennett, \& Adams, 2011). Humour explores and challenges taboos, as they form tacit premises in jokes. Humour can be a playful and creative way (Ackermann, 2015) to help release emotional tension or stress (Lintott, 2016; Morreall, 2014) and challenge norms (LaFollette \& Shanks, 1993), but it can also create offensiveness (Gaut, 1998). As such, joking or being humorous is a complex and multifaceted, volatile event that can comprise the affective response to the joke, the cognitive conceptual core of the joke and the release of pent-up tension and energy (Lintott, 2016). It is possible that Greta was making fun of either the boys or the mathematical task by using what she referred to as a joke to position herself as superior in this situation. Morreall (2014) explained that people's own mirth may be evoked when "something indicates that they are winning in the competition, or that others are losing, especially if their perception of their superiority comes over them quickly" (p. 123). The essence of mirth can signify superiority in relation to something or somebody. Consequently, when mirth is shared, it implies membership in a normatively defined superior group while simultaneously diminishing and excluding Other(s). Thus, a joke can be the gesture of an offensive act of domination from the perspective of the subordinate, while justified as "good humour or a bit of sport" by superior groups (Gaut, 1998). In this sense, to appreciate a joke means to create superior positions, which also serves to create inferior ones. Hence, to the excluded Other, a joke can function as an aggressive reaction veiled in mirth. From this perspective, it is possible to understand Greta's joke as an offensive (in)excluding act.

However, since joking is such a multifaceted and volatile event, it is possible to capture the same event in different ways. Hence, Greta's joke might also be considered a way to open up a playful creative space in which taboos and implicit norms can be exposed and challenged (Ackermann, 2015). From this perspective, humour can be a reaction to something that violates or challenges a person's way of thinking (Hurley et al., 2011; Morreall, 2014). In stand-up comedy, the comedian often elicits expectations from the audience framed within a particular belief system and then delivers a punchline that violates those expectations to evoke laughter (Morreall, 2014). In such cases, incongruity exists between the setup narrative and the punchline, which triggers a sudden recognition and resolution of "faulty reasoning" (Hurley et al., 2011). Captured this way, humour has the potential to challenge norms as it unveils assumed normative beliefs, highlighting the relationship between the laughable and the absurd. In this way, one can claim that Greta's joke challenges certain norms embedded in the prevailing discourses of school mathematics. From this perspective, the lack of mirth among the rest of the students could be explained by that Greta's classmates did not perceive the faulty reasoning on the inordinate use of precision (i.e., measuring exactly) in a task that did 
not require it, and therefore did not experience the incongruity that Greta had already perceived.

Considering the multifaceted complexities of humour and joke-events discussed above, we can broadly consider Greta's utterance as an attempt at a joke because it can be understood either as a veiled act of superiority or as a playful challenge to norms around precision. However, we need to point out that we do not have access to Greta's exact intention in making this joke; indeed, she might not know either. The joke was delivered at the spur of the moment during a mathematical activity on angles (see Episode 1 at the beginning of this section). As we discussed Episode 1, we found that Greta's joke became ambiguous. But, based on experience of enacting analytically with a joke-event in previous work of the second author (Chronaki \& Matos, 2010, 2014), we turned to explore various interpretations by asking what are the joke-event's meanings and effects for student participation in tasks that require precision? Since the joke pivots around the distinction between $90^{\circ}$ and $91^{\circ}$ and measuring angles exactly, we argue that one cannot appreciate Greta's joke on precision if its significance remains detached from the place and role of precision in the school mathematics discourse.

Here, we use the notion of discourse to grasp normative aspects of students' (and teachers') utterances in the mathematics classroom. We specifically note how epistemological discourses that privilege a normative approach to precision (in the realm of accuracy and certainty) underpin learning goals for students' work on mathematical task assignments (e.g., Nachlieli \& Tabach, 2019; Santos \& Semana, 2015). This discourse tends to create the context for students to participate not only to learn but, mainly, to perform (in the realm of evaluation or assessment) a competitive process where success and failure are either explicitly or implicitly framed around skills and competences in being precise. It was in this context that Greta's joke provided an opening to discuss the role of precision both in classroom discourse and in the joke-episode itself.

In Section 2, we discuss recent curricular guidelines in Sweden to uncover assumptions concerning the place of precision in school mathematics as a normative frame for students' participation in mathematics tasks. In Section 3, we encounter the joke-event as a theoretical and methodological opening for reconsidering precision in classroom life. Section 4 explains the context of the study. In Section 5, we provide our interpretative analysis of the joke-event. Concluding remarks are in Section 6.

\section{Precision: its place in the school mathematics curriculum}

Although Rowland (2007) has discussed vague language as a linguistic phenomenon where participants avoid full commitment to precise mathematical claims, attention to precision as competence has generally evoked far less interest than, for example, reasoning or problem-solving (Otten, Engledowl, \& Spain, 2015). Nevertheless, the implicit goal of being precise in mathematical tasks plays a pivotal yet covert role in discourses related either to accuracy in tasks that require students to reason with "true" judgement (Rowland, 2007). Precision becomes a drive for school mathematics in both classroom practice and assessment. Contemporary reforms at global or national levels tend to amplify the place of precision in school by emphasising the need for developing early habits around precision as a virtue in life closely linked to enacting the desired citizen (e.g., Yolcu \& Popkewitz, 2019). We realise that interpreting, by means of a jokeevent, how students engage with precision in mathematical tasks that requires a revisit on 
how precision is enacted around curricular guidelines as they supposedly influence classroom discourse.

Since the joke-event was situated in a Swedish school context, we explore the role of precision in Swedish compulsory schooling by examining a range of curricular documents (see Table 1). These are as follows: the Swedish National Syllabus for mathematics education (Skolverket, 2018), which draws heavily on competences (Niss \& Højgaard, 2019); documents published by the Swedish National Agency for Education (Skolverket) written to operationalise the Syllabus' intentions and to support teachers for theory-informed praxis; and documents from the National Agency of Education written by scholars and launched for professional development called Boost for Mathematics (Matematiklyftet) reaching $75 \%$ of the teacher population (Österholm, Bergqvist, Liljekvist, \& van Bommel, 2016). We also examine material on assessment training for mathematics teachers focusing on high-stakes tests or student activity. Based on electronic documents, we searched for phrases that included the word precision (precis), its synonyms, such as accurate (korrekt or riktig), exact (exakt) or certain (säker), and its antonyms, such as vague (vag), imprecise (oprecis) or uncertain (osäker). In Table 1, we provide specific pages of the documents we found in our search (all quotes below were translated by the first author). However, the Swedish school context and its policy documents are far from isolated from the rest of the world. Due to high-stakes international testing programmes such as PISA and TIMSS, national educational policies are becoming increasingly harmonised throughout the globe (Tröhler, 2010). Therefore, the analysis below to some extent relates to school contexts beyond Sweden.

Although the National Syllabus makes no explicit reference to precision, it mentions precision in the context of "[p]robability, chance and risk [that is] based on observations, simulations or statistical material from everyday situations" (Skolverket, 2018, p. 58). The Syllabus declares that students should learn "[m]ain methods of calculating using natural numbers and simple numbers in decimal form when calculating approximations" (Skolverket, 2018 , p. 57). Imprecision (as uncertainty or vagueness) was also mentioned in Boost for Mathematics on Geometry, where Bennet and Löwing (2015a) noted, "how the more precise

Table 1 Precision in Swedish curricular documents. The document Boost for Mathematics on Geometry comprises 8 parts with short texts. $2: 1$ in table 1 stands for part 2, text 1 . The full references of the texts are found in Appendix

Document

National Syllabus in Mathematics (Skolverket, 2017)

Boost for Mathematics, Geometry for Years 4-6. (The document Boost for Mathematics comprises eight parts with short texts written by Swedish mathematics education scholars. 2:1 stands for part 2 text 1 . The full references of the texts are found in Appendix.)

Assessment Training for Teachers in Mathematics Year 6 (Pettersson, 2013/2017)

National Test in Mathematics for Year 6, 2014/2015 (Skolverket, 2015)

Teacher Instructions including Part A for National Test in Mathematics for Year 6 2014/2015 (Skolverket, 2015)

Assessment Instructions for National Tests in Mathematics for Year 6, 2014/2015 (Skolverket, 2015)
Precision categories and pages

Method: p. 14-15, 29

Register: p. 9, 30

Method: $2: 1$, p. $9-10 ; 3: 1$, p. $1-2 ; 3: 3$, p. $1 ; 7: 1$, p. 10,$12 ; 7: 2$, p. $11 ; 8: 1$, p. $2-3,6-7$.

Register: $1: 1$, p. $1,3-4 ; 4: 1$, p. 4-5; 5:1, p. 1-5; $5: 2$, p. 1,$4 ; 6: 1$, p. $2 ; 7: 1$, p. 11.

Register: p. 1

Method: Parts B-D in 43 of 53 test items

Register: Part A

Method: p. 17

Register: p. 22

Method: p. 5, 8-17, 19-22, 24, 26-35, 38, 46 
mathematical language replaces the vague everyday language" (p. 4), making uncertainty appear irrelevant in the face of mathematical register sufficiency.

Based on content readings and the search for phrases and words mentioned above, we conducted a thematic content analysis (Braun \& Clarke, 2006). Two thematic categories emerged: precision as method and precision as register, and we discuss them below. The category of precision as method emphasises ways of engaging in mathematical activity using accuracy methods, instruments, language, or proof. It appeared in documents describing classroom tasks or test items that require only one correct solution. The one-preciselycorrect-solution practice is common in Swedish textbooks as well as in other contexts (Andersson \& Wagner, 2018), such as the majority of tasks (43 of the 53 items) in the 2014/2015 National Test (Skolverket, 2015) (see Fig. 1 below for an example). Precision as method frame assessment purposes and is "characterised by its symbolic language, which is compact, concise and very precise. Definitions and claims must be crystal clear" (Pettersson, 2013/2017, p. 1).

The Teacher Instructions for the National Test Group Task (Skolverket, 2015) instructs teachers to "keep as neutral as possible, for example [they should] not confirm if the students answer correctly or incorrectly" (p. 17), stressing a distinction between correctness and incorrectness as essential, since it excludes vagueness and/or imprecision. Precision has also been used as the criterion for assessing student work in mathematical tasks and, at times, as an indicator for student performance, skills and competences (e.g., Torbeyns \& Verschaffel, 2013). In the Swedish context, Boistrup (2017) noted that assessment discourses relating to what we call the one-precisely-correct-solution norm have been adopted even in informal assessment settings in and out of the school classroom.

Since Greta and her peers in Episode 1 were drawing and measuring angles, we looked for examples in the documents referring to using instruments. Despite the lack of explicit examples, one text from Boost for Mathematics on Geometry mentioned geometric constructions by means of compass and ruler. Bennet (2015a) wrote "the purpose of geometrical constructions is not intended for practical use, nor do they provide particularly correct images" (p. 2). In fact, geometric constructions "drawn by freehand where the lengths of sides are correct enough" (p. 2) because geometric "[c]onstructions are to be viewed as mental constructions, rather than constructions accomplished in practice, and the physical constructions that we perform are artefacts, concretisations and visualisations, to grasp our mental geometrical concepts" (p. 2). Bennet's rationale for not attending to precision in the physical world of geometry could

5. Leo has two bags. One suitcase that weighs $15.5 \mathrm{~kg}(2 / 0 / 0)$ and one backpack that weighs $6.7 \mathrm{~kg}$. How much heavier is the suitcase than the backpack? Show your working 7. Write the missing numbers so that each equation is correct.
a)
$+0.8=1.0$
b) $6 \cdot 7=$ $+12$
c) $300-$ $=167$
d) $100 \cdot$ $=30$

Fig. 1 Tasks 5 and 7 from National Test part B for Year 6, 2014/20155 
be explained by an emphasis on reasoning in the Swedish National syllabus (Skolverket, 2018). In contrast, Niss and Højgaard (2019) claimed that students need precision skills to communicate visually. Their claim resonates with what is desired in mathematical reasoning, namely that students can "describe methods by the use of more precise and developed mathematical representations" (Skolverket, 2017, p. 30) where visual diagrams are included. So, while precision appears unimportant in geometry, it becomes essential in visual communication. In the Swedish National Syllabus, precision as method seems to disappear as a requirement but becomes visible when the norm of the one-precisely-correct-solution is often found in curricular guidelines.

The category of precision as register refers to mathematical language use (Pimm, 1987). According to the Assessment Training for Teachers, mathematical register is "compact, concise and very precise" and "crystal clear" (Pettersson, 2013/2017, p. 1). Österholm and Bergqvist (2013) explored the prevailing idea that mathematical texts are "highly compact, precise, complex, and containing technical vocabulary" (p. 751), noting the lack of empirical support for such claims. The Commentary Material (Skolverket, 2017) conforms to the idea of mathematical language use as a matter of being precise, stating that "[i]t is only when students have developed the competence to communicate mathematics [with precision] that mathematics may develop into a functional tool" (Skolverket, 2017, p. 9). Such indications stress precision as register for making communication functional and argue that instruction should "give the students opportunities to develop an increasingly more precise mathematical language, [which will allow them to] adjust their conversations and statements to different recipients or purposes" (Skolverket, 2017, p. 9).

Teachers should scaffold mathematical language, which among other things "means that the subject objectives and the language mastery objectives are explicit [to the students]" (Löwing, 2015, p. 2). It is further claimed that "teachers must develop the norm to use accurate terminology. You [as the teacher] must have a norm for what [mathematical] language you use yourself and a norm for how you correct students' language when needed" (Bennet \& Löwing, 2015b, p. 7). In addition, some prescribe how teachers may "write the mathematical terminology on the board and highlight language when students use everyday language when it is possible to use a more precise mathematical language instead" (Bennet, 2015b, p.12). Otten et al. (2015) problematised such prescriptions and noted how students become quiet in whole class conversations that emphasised an explicit attention to precision. For them, attention to precision was a privilege or responsibility of the more knowledgeable teacher. Related, Rowland (2007) noted how students use vague language to handle skew power relations that oblige them to conform to mathematics teachers' (oblique) requests for clarity and precision. The use of vague language allows students to redress the power imbalance while at the same time acknowledging the normative framing that constrain their actions and responses.

Despite pedagogical efforts to appreciate diversity in mathematical activity (e.g., Stein, Engle, Smith, \& Hughes, 2008), mathematical tasks eventually tend to become a matter of being right or wrong (de Freitas \& Sinclair, 2014; Andersson \& Wagner, 2018). When students ultimately are expected to produce a one-precisely-correct-solution, they are at the same time exposed to the risk of being "precisely wrong" (Ryan, 2019). Precision as a method and register creates a normative framing when students engage with mathematical activity. It is in this context that Greta's joke about precision emerged. In the next section, we consider the significance of this normative framing for the joke-event. 


\section{A joke-event: opening up theoretical and methodological considerations}

In Greta's joke-event, the students encountered two tasks requiring them to reason about measuring angles. According to Lithner (2008), mathematical reasoning is both social and rational. Both dimensions deal with claims - the social in producing an argument and the rational in stressing its validity. In the mathematics classroom, these two may intersect (Yackel \& Hanna, 2003), shaping both a social and a cognitive content-based dimension that reciprocally frame the situation. The joke-event fits within a process of mathematical reasoning where students assess claims by giving and asking for reasons for claims to produce strong arguments about angles.

To grasp simultaneously the social and the cognitive content-based space that framed the joke-event, we consider it a social epistemic space by using the notion of space of reasons as conceptualised within the theory of inferentialism (Brandom, 1994, 2000). Bakker and Derry (2011) employed the notion of webs of reasons (Brandom, 1994) as a more precise notion than context to consider all relevant reasons involved in a pedagogical situation in which students learn to draw informal statistical inferences. Webs of reasons, Brandom (1994) explained, highlight content and concerns about how one conceptual content inferentially relates to some other conceptual content. What inferential relations may and may not do among concepts are matters of normativity. This means that webs of reasons are submerged in a socially normative space, the space of reasons. Here we use the idea of space of reasons to help us perceive the significance of Greta's joke in a realm that normatively privileges precision as a method and as a register. Brandom (1995) explained that spaces of reasons are abstractions of people's practical face-to-face giving and asking for reasons for claims. This practice creates a social epistemic space because:

[i]f one individualizes the space of reasons, forgetting that it is a shared space within which we adopt attitudes towards each other - and so does not think about standings in the space of reasons as socially articulated, as potentially including the social difference of perspective between attributing and undertaking commitments, that is, between your standing and mine - then one will not be able to understand knowledge as a standing in the space of reasons. (Brandom, 1995, p. 904)

At the heart of the space of reasons is the idea of normative responsiveness to reasons (Bakhurst, 2011). This means that the standings we give to claims in the space of reasons are matters of normativity. In the context of this paper, the space of reasons allows us to consider the normative epistemic space in which the four students reasoned about angles. In this space, students experienced the tension of being in-between recognising what is taken as normative, what is not, or even what undergoes transformation (Bakhurst, 2011). On the one hand, norms embedded in practices can be made explicit and even transformed through the process of reasoning, since reasoning "can help us make explicit (and hence available for criticism and transformation) the [norms] that govern the use of all our vocabulary, and hence articulate the contents of all our concepts" (Brandom, 2000, p. 30). On the other hand, standings that do not conform to what is normatively appropriate may evoke negative sanctions (Brandom, 1994). A claimer who cannot produce normative appropriate reasons may be exposed to negative sanctions and might therefore become excluded from having the social status of being a reliable knowledge claimer. For the evolving playfully competitive situation among Greta and her peers, this meant that if students could not produce normatively 
appropriate reasons for their claims within the school mathematics normative epistemic space, the team would fail, and become constructed as losers.

According to LaFollette and Shanks (1993), to appreciate humour, one must have beliefs interconnected to each other in what they refer to as related epistemic spaces. These epistemic spaces provide a complex array of perspectives or narrative frames to interpret events, which allows someone to appreciate the joke from a variety of normative positions. While there might be normatively good reasons for a claim within one normative framing (or space of reasons) but when the normative framing in action is changed, the reasons given may seem inappropriate or even absurd. The multiple normative framings that someone can evoke might arise from oblique knowledge and from the creative ability to imagine "what if" worlds into which they venture off to see what alternative framings might mean (Ackermann, 2015).

A joke has the potential to challenge a normative, undisputable and yet core aspect of social life as it makes the complexity of this very same aspect visible (Ackermann, 2015). Therefore, events of humour can constitute useful methodological tools that can "provide insights into behavioural and cultural patterns of societal relations and support to express, to describe and to evaluate taken for granted institutional symbols, relations and values" (Chronaki \& Matos, 2010 , p. 220). In this light, we argue that Greta's joke may illuminate how we can recognise and cope with tensions that are inherent in prevailing norms of precision.

\section{The context of the study: students, setting and tasks}

In this section, we illuminate the context in which Greta's joke occurred - the setting, the tasks, the participants and the joke itself.

\subsection{Greta, her peers and the mathematics class}

Greta and her peers Samir, Darko and Eva were grade 5 students, aged 11. Their school was in a middle class suburban community in South Sweden. Some pupils commuted to the school from socio-economically deprived areas nearby. In interviews, all four students claimed to be confident with mathematics, reporting the subject's importance for academic success. In classroom observation, they usually acted friendly towards one another, helping each other during lessons on several occasions. Hence, their relationship appeared safe for joking (Ackermann, 2015), providing good grounds for a "joking license" (Handelman \& Kapferer, 1972, cited in Chronaki \& Matos, 2010) - a context in which people can joke and tease without damaging their friendship.

The grade 5 class was multilingual, but with no shared languages. Greta and Eva spoke Swedish, which was the language of instruction. Darko, born in Sweden to immigrant parents, spoke Serbian and Swedish. Samir was an emergent Swedish speaker who spoke Arabic and Hebrew at home. The class teacher was engaged in professional development courses and was interested in creating a classroom pedagogy based on exploratory talk to support students' reasoning skills. Therefore, the students were familiar with the type of task they were occupied with when Greta delivered her joke.

\subsection{The setting and the task}

As Greta delivered her joke, the four students were working on two related tasks the teacher had written on the board. The first task was about drawing three angles and measuring them with a protractor, while the second was on reasoning about types of angles (see Fig. 2 below). 


Task 1
Draw three angles. Make one acute,
one right and one obtuse. Let the
other pair of students measure and
denote your angles using a
protractor.

Fig. 2 The two tasks on measuring and reasoning
Task 2

Draw three angles. Make one acute, one right and one obtuse. Let the other pair of students judge which is which and give reasons for why they claim each angle to be either acute, straight or obtuse.

The tasks were meant for collaborative work among pairs. Greta and Eva formed one pair and so did Darko and Samir. The empirical material we used for analysis consists of a transcript from a 44-min audio-recorded lesson interaction. The material comprises 519 turns. Ulrika (the first author) translated the verbatim transcripts from Swedish to English. We are aware that although the experience of translation may seem a relatively straightforward matter, language nuances may influence not only our but also the readers' focus and interpretation of the transcript excerpts.

\section{Interpreting the joke-event}

The social space that emerged and evolved as the two student pairs (Greta and Eva, and Darko and Samir) worked on the tasks was framed within experiences of contest and competition and acts of giving and asking for reasons. Although expressed playfully, throughout the whole interaction, there was talk about being the best, not revealing one's ideas, and giving points. Table 2 below displays part of the interaction that occurred after Greta delivered her joke, in which a debate unfolded among the four students about points for correct angle denotations for task 2.

Although this excerpt does not show how the students give and ask for reasons for their claims, it reveals the normative epistemic space in which their claims were given and assessed as normatively appropriate. The normative framing resonates with the one-precisely-correctsolution norm, which stresses the precise distinction between correctness and incorrectness. The significance of the distinction is made explicit in turns 296, 299, 300, 301 and 303. Below (see Table 3), we proceed to consider how the normative framing shapes the giving and asking for reasons. In turn 115, Greta asked the boys to give reasons for claiming that one of the girls' angles was $100 / 80^{\circ}$, using the two numbers directly above each other on the protractor to denote the angle. She asked them to choose one of the two numbers. In turn 116, Darko asked Samir to decide what number to choose. In turn 117, Samir appeared reluctant to make the decision as he replied "one of them" instead of saying which one, as if he was trying to escape the risk of being precisely wrong (Ryan, 2019) and thus being potentially exposed to negative sanctions (Brandom, 1994).

In turns 119 and 121 , Samir gave reasons for the boys' denotation of $80 / 100^{\circ}$ by asking the girls to look at the protractor to see that 100 and 80 are located at the same position directly above each other. Therefore, his denotation ought to be correct, he claimed. Their discussion 
Table 2 Excerpt 1: Debate about points given for correct angle denotations

\begin{tabular}{llll}
\hline Turn & Speaker & Original Swedish & English translation \\
\hline 296 & Samir & Ni har ett fel och två rätt... & You have one wrong and two correct... \\
297 & Greta & Sedan när & Since when \\
298 & Darko & Den var. en och femtiofem & It [THE ANGLE] was one and fifty-five [155] \\
299 & Samir & Ni har alla fel förutom två & You did all wrong except for two [ANGLES] \\
300 & Greta & Det kan inte vara fel. Vi behövde ju bara skriva & It cannot be wrong. We just had to write if it \\
& & om den var. spetsig trubbig eller rät. Det & [THE ANGLE] was acute, obtuse or right. It \\
& & spelar ju ingen roll om vi skrev hur stor & does not matter if we wrote how big the \\
& & vinkeln var & angle was \\
301 & Samir & Jaha då hade ni halvrätta & Oh then you had half corrects \\
302 & Darko & Två och en halv & Two and a half [POINTS] \\
303 & Samir & Och vi hade allt rätt...hade vi allt rätt? & And got everything correct...did we get \\
& & & everything correct? \\
\hline
\end{tabular}

highlights differences in how the two students acknowledge what is a normative way to measure angles. Greta has undertaken the conventional way of measuring angles, while Samir (and Darko) has not (yet) done that. A similar discussion followed. This time, Greta enthusiastically claimed and now convinced the boys that it is impossible to say that an angle is both $40^{\circ}$ and $140^{\circ}$ at the same time. In virtue of the normative framing that the one-preciselycorrect-solution norm allows for, Greta's claims were positioned as "true" knowledge claims because her reasons echoed mathematical claims that require precisely one or the other.

In the epistemic space of reasons that emerged during the students' work on the two tasks on angles, they appeared to recognize knowledge as a matter of distinctions between precise correctness and precise incorrectness. In the context of the emerging competition between the girls and the boys, this meant that the more precisely correct the combatants were, the more "true" standings their claims would occupy in the space of reasons and the more points they would earn in their playful competition. It is in this epistemic and normative space of reasons that we interpret Greta's emphasis on precision as shown in Table 4 below, as she mediated Eva when she was busy drawing the angles for the boys to judge in task 2 .

Table 3 Excerpt 2: Measuring and reasoning about angles

\begin{tabular}{|c|c|c|c|}
\hline Turn & Speaker & Original Swedish & English Translation \\
\hline 115 & Greta & $\begin{array}{l}\text { Vad då slash } 80 \text { grader. Ni får } \\
\text { ju välja någonting }\end{array}$ & $\begin{array}{l}\text { What [DO YOU MEAN] slash } \\
80 \text { degrees. You must choose } \\
\text { something }\end{array}$ \\
\hline 116 & Darko & Samir & Samir \\
\hline 117 & Samir & En av. dem & One of them \\
\hline 118 & Greta & Ni får välja & You must choose \\
\hline 119 & Samir & $\begin{array}{l}\text { Ja bara kolla. Den är samma. } \\
\text { Den är } 100 \text { och } 80 .\end{array}$ & $\begin{array}{l}\text { Yes just look. It [THE ANGLE] is } \\
\text { the same. It is } 100 \text { and } 80 .\end{array}$ \\
\hline 120 & Greta & $\begin{array}{l}\text { Ja men nej. Det kan ju inte } \\
\text { vara både och }\end{array}$ & Yes but no. It cannot be both and \\
\hline 121 & Samir & Jo dom är över varandra & $\begin{array}{l}\text { Yes [IT CAN] because they are above } \\
\text { each other }\end{array}$ \\
\hline 122 & Greta & $\begin{array}{l}\text { Ja men dom...men det betyder } \\
\text { ju inte att det är samma. Den } \\
\text { är ju inte } 100 \text { slash } 80 \text {. Den är } \\
\text { ju en av. dom }\end{array}$ & $\begin{array}{l}\text { Yes but they...it does not mean that it } \\
\text { is the same. It [THE ANGLE] is not } \\
100 \text { slash } 80 \text {. It is one of them }\end{array}$ \\
\hline
\end{tabular}


Table 4 Excerpt: Greta urges Eva to be exact

\begin{tabular}{|c|c|c|c|}
\hline Turn & Speaker & Original Swedish & English translation \\
\hline 212 & $\begin{array}{l}\text { Greta } \\
\text { [TO } \\
\text { EVA] }\end{array}$ & $\begin{array}{l}\text { Kolla om de är exakt lika dana om de är exakt } \\
\text { lika dana...du făr göra den lite längre }\end{array}$ & $\begin{array}{l}\text { Check if they are exactly the same if they are } \\
\text { exactly the same...you must make that } \\
\text { one a bit longer }\end{array}$ \\
\hline--- & & & \\
\hline 214 & Greta & Exakt exakt exakt [TILL EVA SOM RITAR] & $\begin{array}{l}\text { Exact, exact, exact [TO EVA WHO IS } \\
\text { DRAWING] }\end{array}$ \\
\hline
\end{tabular}

Greta encouraged Eva to be exact and to use a precise method when drawing the right angle. As the girls handed over the three angles to the boys, the competition was in full spirit. Greta brought forth the idea of using the protractor to measure the right angle drawn by the boys despite that teacher's instruction not to measure, but to look at and judge whether an angle was acute, right or obtuse. It is interesting to note an intrinsic pedagogical tension in the second task where Greta urges to be exact when diagramming the right angle articulates. Acute and obtuse angles can take on an array of possible angles. By definition, a right angle can take on just one, $90^{\circ}$. This tension adds to the complexity that framed the joke-event and the joke itself (turn 269) as part of the interaction shown in Table 5 below.

The joke fell flat. None of the other students laughed or showed any signs of mirth. Rather, Samir appeared bewildered responding by saying "what" in turn 270 . In turn 271, Greta tried to clarify the joke. Together turns 269 and 271 show how the joke begins from the idea that measuring the angle exactly and finding it to be $91^{\circ}$ makes it obtuse and not a right angle as the boys claimed it to be.

Greta's joke and the (lack of) response to it invited us to interpret how it was situated in the normative framing of the space of reasons that emerged during the student interaction by bringing forth theories of humour, the role of precision in the school mathematics discourse and the space of reasons in classroom life. We recognize that students engage in this realm as

Table 5 Excerpt: Drawing angles and joking about accuracy

\begin{tabular}{|c|c|c|c|}
\hline Turn & Speaker & Original Swedish & English translation \\
\hline 265 & $\begin{array}{l}\text { Greta } \\
\text { [TO } \\
\text { EV- } \\
\text { A] }\end{array}$ & Nej inte [OHÖRBART] grader, kolla. & No not [UNHEARABLE] degrees, check. \\
\hline 266 & Darko & Vad positiv du är Greta. & How positive you are Greta. \\
\hline 267 & Greta & Den är 91 grader. & It is 91 degrees. \\
\hline 268 & Samir & Vi är klara. & We are done. \\
\hline 269 & Greta & $\begin{array}{l}\text { Det är inte en rät vinkel...Det är en trubbig } \\
\text { vinkel. Det är ingen rät vinkel. Den är } \\
\text { 91[GRADER]. }\end{array}$ & $\begin{array}{l}\text { It is not a right angle... It is an obtuse angle. It } \\
\text { is not a right angle. It is } 91 \text { [DEGREES]. }\end{array}$ \\
\hline 270 & Samir & Vad? & What? \\
\hline 271 & Greta & $\begin{array}{l}\text { Jag skojade bara...Alltså om man mäter det } \\
\text { exakt så är den... }\end{array}$ & $\begin{array}{l}\text { I was just joking... That is if you measure it } \\
\text { exactly it is... }\end{array}$ \\
\hline 272 & Samir & Ja, ska jag lämna... & Yes, I am going to hand over... \\
\hline 273 & Darko & [OHÖRBART] för att jag sa... & [UNHEARABLE] because I said... \\
\hline 274 & Samir & $\begin{array}{l}\text { Ja, ska jag lämna den till dom. Var så god att } \\
\text { rätta...vänta ni har fel på [UPPGIFT] a. Ni } \\
\text { skrev inte hur mycket grader den är. }\end{array}$ & $\begin{array}{l}\text { Yes, I will hand it over to them [THE GIRLS]. } \\
\text { Please mark this... wait you made a mistake } \\
\text { in [TASK] a. You did not write how much } \\
\text { degrees it is. }\end{array}$ \\
\hline
\end{tabular}


they experience the tension of being in-between recognising what is taken as normative, what is not, or even what undergoes transformation (Bakhurst, 2011). This tension seems to shape two modes of interpretation. The first mode refers to how the joke mirrors the school discourse of "precision" by conforming to the precision "norm" and the second shows how the joke can challenge the pursuit of precision in mathematical tasks.

\subsection{The joke as a way of conforming with the "precision" norm}

Greta's joke constituted an event that capitalised on mathematical precision norms to produce a veiled aggression (Gaut, 1998) directed towards the boys. Greta's sense of superiority was positively sanctioned in the school mathematics discourse on precision. Her mastery in mathematical precision was exemplified when she pointed out that it is impossible to denote an angle as both $40^{\circ}$ and $140^{\circ}$ and in her excitement as she encouraged Eva to be "exact, exact" in diagramming the angles. In these enactments, we understand Greta's joke as manifesting her conformity to the precision norm. Greta acted as a teacher who attended to precision during the joke-event while the boys, in the same vein of observations made by Otten et al. (2015), become quiet as they appeared to accept their subordinate position created when Greta asserted the normative appreciation of precision in the mathematics classroom discourse.

\subsection{The joke as challenging the norm of "precision"}

Greta's joke-event seemed not only to highlight but also to challenge the normative epistemological appreciation of precision that underlies the task of constructing angles in classroom practice. The joke and the process of joking, when set together to challenge the norm, can become a powerful act as it can transform and change our belief systems or make us see a different perspective in a situation (LaFollette \& Shanks, 1993). In this way, one can claim that the joke challenges dominant views, such as prevailing views on precision, and becomes a way to relate with power through the voice of laypeople.

This second mode of interpretation departs from the view that the essence of the joke is a suddenly experienced absurdity originating from the normative epistemic framing of school mathematics, which produced Greta's emphasis on precision and made her urge Eva to be "exact, exact" when drawing the angles. It is the same normative epistemic space that made the competition possible at all and allowed Greta to say that it is impossible to use double denotation as the boys did. Within this normative epistemic space, the emerging competition seemed perfectly normal. However, as Greta revisited the situation, she was overwhelmed by her own obsession with precision, realising that the precision norm could be challenged and a differently framed of space of reasons could emerge. This shift in normative framing of the space of reasons allowed Greta to recognise some absurdity in the reason-giving that, a moment ago, seemed perfectly normal. This recognised absurdity lay in her own pursuit for certainty, accuracy and precision and became unveiled when she claimed by her joke that overrelying on the precision discourse did not conform with the physical constraints in the tasks. In this interpretation, Greta perceived an absurdity in the demand for students to, on the one hand, use precision in performing technical skills to visually communicate mathematics (Niss \& Højgaard, 2019) and, on the other hand, perform a cognitive activity that demands precision not in geometrical constructions but in geometry reasoning (Bennet, 2015a). To experience this absurdity and to shift the normative framing of the space of reasons, Greta had to both recognise the norm of precision and acknowledge mathematics as dynamic, uncertain and 
imprecise. However, while Greta experienced this tension and delivered her joke as a challenge to the precision of mathematics, the other students' activities were still strongly framed by it. Hence, the joke fell flat.

\section{Concluding remarks}

The joke-event invited us to revisit the status of precision in school mathematics discourse and to explore, on the one hand, student participation in school mathematics tasks that require precision through two modes of interpreting the joke on precision and, on the other hand, the role of precision in curricular documents. Together, the two level analyses can shed light on the place of "precision" as competence in mathematics education.

First, we wish to note that although research so far has paid less attention to how precision plays out in the mathematics classrooms as compared with reasoning or problem-solving (Otten et al., 2015), norms of precision as method and register significantly influence both processes of educational policy and processes of teaching and learning in the realm of classroom life in the Swedish context (and beyond). By exploring the place of precision in curricular documents that support teachers in operationalising the National Syllabus, it became evident that precision either as method (i.e., ways of working in school mathematics) or as register (i.e., correct use of mathematical language) determines classroom practice in a range of situations such as textbook and group tasks, teacher instruction, scaffolding and assessment. As such, the norm of precision influences students' ways of working and provides spaces of reasons (Brandom, 1995) for students to exercise their claims and to construct social status in the realm of school mathematics discourse. In the case of Greta and her peers, the precision norm allowed Greta and Eva to experience a superior social status of knowers and winners while, at the same time denying Darko and Samir that same status.

Classroom norms on precision should, according to the curricular documents we scrutinised, form students' mathematical behaviour (Bennet \& Löwing, 2015b). However, norms on precision also form students' social attitudes towards each other's claims as they engage in reasoning activities (Brandom, 1995). This means that asking students to conform to the precision norm - to master precision as a method and as a register - is not a neutral practice. Rather, it involves asking them to engage in spaces of reasons where they produce negative sanctions towards one another. This may explain why students refrain from engaging in whole class discussions in which they are asked to pay attention to precision norms (Otten et al., 2015) or why they use vague language in conversations with superiors like teachers or researchers (Rowland, 2007). We suggest that attention to precision needs to be handled with care in the mathematics classroom. If teachers and students discuss the role of precision in measuring and reasoning activities, imprecise claims can become accepted as having the status of being normatively appropriate in the school mathematics spaces of reasons. Attention to imprecision in mathematics classroom talk is also suggested by Rowland (2007), because after all, imprecision has an equally profound role in disciplinary mathematics (Maheux, 2016; Yolcu \& Popkewitz, 2019).

Second, we remark that our two modes of interpreting Greta's joke reveal a space of double tension that the students may experience by being in-between what is being taken as the norm (conforming to the norm) and the possibility of its transformation (challenging the norm) (Bakhurst, 2011). Greta's joke calls to our attention that it is not unproblematic for students to find themselves in the midst of this tension. Rowland (2007) noted how students deal with tensions related to power and precision by the use of vague language. In contrast, Greta, by 
means of the joke, appears to call out the tension and illuminate it. However, the other students did not laugh, perhaps because they did not want to endorse Greta's superiority and/or her challenging; Greta appears to experience her joke in solitude. We suggest that mathematics education in general and teaching approaches in particular need to support students in experiencing processes of being in-between conforming with the precision norm of school mathematics and challenging it collectively. After all, mathematics has been always simultaneously social, cultural and political.

Funding Information Open access funding provided by Malmö University.

\section{Appendix}

Full references for the documents from the Boost for Mathematics.

\section{Part number:text Reference}

number

1:1 Bennet, C. \& Löwing, M. (2015). Geometri - en kort inledning [Geometry- a short introduction]. Matematiklyftet. Stockholm: Skolverket.

Bennet, C. (2015). Att undervisa utifrån en didaktisk ämnesanalys [To teach from a didactic subject specific analysis]. Matematiklyftet. Stockholm: Skolverket.

Bennet, C. (2015). Ett klassrumsexempel [A classroom example]. Matematiklyftet. Stockholm: Skolverket.

Löwing, M. (2015). Bedömning och undervisning [Assessment and teaching]. Matematiklyftet. Stockholm: Skolverket.

Lingefjärd, T. (2015). Representationer och lärande [Representations and learning]. Matematiklyftet. Stockholm: Skolverket.

Bennet, C. (2015). En aktivitet kring olika representationer [An activity around different representations]. Matematiklyftet. Stockholm: Skolverket.

Bennet, C. \& Löwing, M. (2015). Judy och Matteo resonerar [Judy and Matteo reason]. Matematiklyftet. Stockholm: Skolverket.

Löwing, M. (2015). Undersökande arbetssätt i geometriundervisningen [Investigations in geometry instruction] Matematiklyftet. Stockholm: Skolverket.

Bennet, C. \& Löwing, M. (2015). Möbiusband - en laboration [Möbius strip - a laboration]. Matematiklyftet. Stockholm: Skolverket.

Bennet, C. \& Löwing, M. (2015). Rosi-Anne undervisar om volym [Rosi-Anne teaches about volume]. Matematiklyftet. Stockholm: Skolverket.

Löwing, M. (2015). Geometriundervisning med focus på språkutveckling [Geometry instruction with a focus on language development]. Matematiklyftet. Stockholm: Skolverket.

Jacobson, M. (2015). Idéer för språkutvecklande undervisning [Ideas for language developing instruction]. Matematiklyftet. Stockholm: Skolverket.

Essén, G. \& Hägglund, U. (2015). Sex geometrilektioner som gjorde skillnad. [Six geometry classes that made a difference]. Matematiklyftet. Stockholm: Skolverket.

Bennet, C. (2015). Aspekter på konstruktioner i geometrin [Aspects on geometrical constructions]. Matematiklyftet. Stockholm: Skolverket.

Bennet, C (2015). Fyra konstruktionsproblem [Four construction problems]. Matematiklyftet. Stockholm: Skolverket.

Bennet, C. (2015). Att resonera i och om geometri [To reason in and about geometry]. Matematiklyftet. Stockholm: Skolverket.

Bennet, C. \& Lingefjärd, T. (2015). Om geometri - en historisk exposé [About geomerty a historical exposé]. Matematiklyftet. Stockholm: Skolverket.

Bennet, C. \& Löwing, M. (2015). Normer under matematiklektioner. [Norms during mathemetics class]. Matematiklyftet. Stockholm: Skolverket. 
Open Access This article is licensed under a Creative Commons Attribution 4.0 International License, which permits use, sharing, adaptation, distribution and reproduction in any medium or format, as long as you give appropriate credit to the original author(s) and the source, provide a link to the Creative Commons licence, and indicate if changes were made. The images or other third party material in this article are included in the article's Creative Commons licence, unless indicated otherwise in a credit line to the material. If material is not included in the article's Creative Commons licence and your intended use is not permitted by statutory regulation or exceeds the permitted use, you will need to obtain permission directly from the copyright holder. To view a copy of this licence, visit http://creativecommons.org/licenses/by/4.0/.

\section{References}

Ackermann, E. K. (2015). Amusement, delight, and whimsy. Constructivist Foundations, 10(3), 405-411.

Andersson, A., \& Wagner, D. (2018). Remythologizing mystery in mathematics: Teaching for open landscapes versus concealment. Education in Science, 8(2), 41.

Bakhurst, D. (2011). The formation of reason. London, UK: Wiley Blackwell.

Bakker, A., \& Derry, J. (2011). Lessons from inferentialism for statistics education. Mathematical Thinking and Learning, 13(1-2), 5-26.

Bennet, C. (2015a). Aspekter på konstruktioner i geometrin [aspects on geometrical constructions]. Matematiklyftet. Stockholm, Sweden: Skolverket.

Bennet, C. (2015b). Att resonera i och om geometri [to reason in and about geometry]. Matematiklyftet. Stockholm, Sweden: Skolverket.

Bennet, C. \& Löwing, M. (2015a). Geometri - en kort inledning [geometry - a short introduction]. Matematiklyftet. Stockholm, Sweden: Skolverket.

Bennet, C. \& Löwing, M. (2015b). Normer under matematiklektioner. [norms during mathemetics class]. Matematiklyftet. Stockholm, Sweden: Skolverket.

Boistrup, L. B. (2017). Assessment in mathematics education: A gatekeeping dispositive. In H. Straehler-Pohl, N. Bohlmann, \& A. Pais (Eds.), The disorder of mathematics education. Challenging the sociopolitical dimensions of research (pp. 209-230). Cham, Switzerland: Springer.

Brandom, R. (1994). Making it explicit: Reasoning, representing, and discursive commitment. Cambridge, MA: Harvard University Press.

Brandom, R. (1995). Knowledge and the social articulation of the space of reasons. Philosophy and Phenomenological Research, 55(4), 895-908.

Brandom, R. (2000). Articulating reasons: An introduction to inferentialism. Cambridge, MA: Harvard University Press.

Braun, V., \& Clarke, V. (2006). Using thematic analysis in psychology. Qualitative Research in Psychology, $3(2), 77-101$.

Chronaki, A., \& Matos, A. (2010). Desiring/resisting identity change politics: Mathematics, technology and teacher narratives. In Gellert, U., Jablonka, E.\& Morgan, C. (Eds.), Proceedings of the $6^{\text {th }}$ Mathematics Education and Society Conference. Berlin, 219-228.

Chronaki, A. \& Matos, A. (2014) Technology use and mathematics teaching: Teacher change as discursive identity work, Learning, Media and Technology, 39(1), 107-125

de Freitas, E., \& Sinclair, N. (2014). Mathematics and the body: Material entanglements in the classroom. New York, NY: Cambridge University Press.

Gaut, B. N. (1998). Just joking: The ethics and aesthetics of humor. Philosophy and Literature, 22(1), 51-68.

Handelman, D., \& Kapferer, B. (1972). Forms of joking activity: A comparative approach. American Anthropologist, 74, 484-517.

Hurley, M. M., Dennett, D. C., \& Adams, R. B. (2011). Inside jokes: Using humor to reverse-engineer the mind. Cambridge, MA: MIT Press.

LaFollette, H., \& Shanks, N. (1993). Belief and the basis of humor. American Philosophical Quarterly, 30(4), $329-339$.

Lintott, S. (2016). Superiority in humor theory. The Journal of Aesthetics and Art Criticism, 74(4), 347-358.

Lithner, J. (2008). A research framework for creative and imitative reasoning. Educational Studies in Mathematics, 67(3), 255-276.

Löwing, M. (2015). Geometriundervisning med focus på språkutveckling [geometry instruction with a focus on language development]. Matematiklyftet. Stockholm, Sweden: Skolverket.

Maheux, J. F. (2016). Sort-of-right mathematics. For the Learning of Mathematics, 36(1), 24-25.

Morreall, J. (2014). Humor, philosophy and education. Educational Philosophy and Theory, 46(2), 120-131. 
Nachlieli, T., \& Tabach, M. (2019). Ritual-enabling opportunities-to-learn in mathematics classrooms. Educational Studies in Mathematics, 101(2), 253-271.

Niss, M., \& Højgaard, T. (2019). Mathematical competencies revisited. Educational Studies in Mathematics, $102,1-20$.

Österholm, M., \& Bergqvist, E. (2013). What is so special about mathematical texts? Analyses of common claims in research literature and of properties of textbooks. ZDM, 45(5), 751-763.

Österholm, M., Bergqvist, T., Liljekvist, Y., \& van Bommel, J. (2016). Utvärdering av Matematiklyftets resultat, slutrapport. Umeå, Sweden: Umeå universitet.

Otten, S., Engledowl, C., \& Spain, V. (2015). Univocal and dialogic discourse in secondary mathematics classrooms: The case of attending to precision. ZDM, 47(7), 1285-1298.

Pettersson, A. (2013/2017). Bedömning av kunskap för lärande och undervisning i matematik. [assessment of knowledge for the learning and teaching of mathematics]. Stockholm: Skolverket Retrieved 20190226 from https://www.skolverket.se/download/18.5dfee44715d35a5cdfa92d3/1516017578191/02-bedomninglarande-och-undervisning-i-matematik-2017.pdf

Pimm, D. (1987). Speaking mathematically: Communication in mathematics classrooms. London, UK: Routledge.

Rowland, T. (2007). "Well maybe not exactly, but it's around fifty basically": Vague language in mathematics classrooms. In J. Cutting (Ed.), Vague language explored (pp. 79-96). Basingstoke, UK: Palgrave Macmillan.

Ryan, U. (2019). Mathematical preciseness and epistemological sanctions. For the Learning of Mathematics, $39(2), 25-29$.

Santos, L., \& Semana, S. (2015). Developing mathematics written communication through expository writing supported by assessment strategies. Educational Studies in Mathematics, 88(1), 65-87.

Skolverket (2015). Ämnesprov i matematik 2014/2015. Bedömningsanvisningar för del A, B, C, D och E. [Subject test in mathematics. Assessment instructions for part A, B, C, D and E]. Retrieved 20190226 from https://www.su.se/polopoly_fs/1.405636.1539325385!/menu/standard/file/Bed\%C3\%B6 mningsanvisningar\%20Delprov\% $20 \mathrm{~B} \% 2 \mathrm{C} \% 20 \mathrm{C} \% 2 \mathrm{C} \% 20 \mathrm{D} \% 2 \mathrm{C} \% 20 \mathrm{E} \% 202015$.pdf.

Skolverket (2017). Kommentarsmaterial till kursplanen i matematik. Reviderad 2017. [Commentary material to the national syllabus in mathematics. Revised 2017]. Stockholm, Sweden: Skolverket.

Skolverket (2018). Lgr 11. Läroplan för grundskolan, förskoleklassen och fritidshemmet 2011. Reviderad 2018. [Lgr 11. Curriculum for the compulsory school, preschool class and school-age childcare. Revised 2018] Stockholm: Skolverket.

Stein, M. K., Engle, R. A., Smith, M. S., \& Hughes, E. K. (2008). Orchestrating productive mathematical discussions: Five practices for helping teachers move beyond show and tell. Mathematical Thinking and Learning, 10(4), 313-340.

Torbeyns, J., \& Verschaffel, L. (2013). Efficient and flexible strategy use on multi-digit sums: A choice/nochoice study. Research in Mathematics Education, 15(2), 129-140.

Tröhler, D. (2010). Harmonizing the educational globe. World polity, cultural features, and the challenges to educational research. Studies in Philosophy and Education, 29(1), 5.

Yackel, E., \& Hanna, G. (2003). Reasoning and proof. In J. Kipatrick, W. G. Martin, \& D. Schifter (Eds.), A research companion to principles and standards for school mathematics (pp. 227-236). Reston, VA: National Council of Teachers of Mathematics.

Yolcu, A., \& Popkewitz, T. S. (2019). Making the able body: School mathematics as a cultural practice. ZDM, 51(2), 251-261.

Publisher's note Springer Nature remains neutral with regard to jurisdictional claims in published maps and institutional affiliations. 